\title{
THE APPLICATION OF EDUTAINMENT METHOD IN DEVELOPING BEGINNER-LEVEL WRITING COMPETENCY FOR STUDENTS OF EARLY GRADE IN ELEMENTARY SCHOOL
}

\author{
By \\ Ni Gusti Ayu Made Yeni Lestari \\ ayuyenilestari88@gmail.com \\ Institut Hindu Dharma Negeri Denpasar Indonesia
}

diterima 5 Agustus 2019, direvisi 15 September 2019, diterbitkan 1 Oktober 2019

\begin{abstract}
Beginner-level writing is one of the dimensions in language development of early grade students in elementary school that need to be focused on. Writing is the final stage of literacy learning. Theoretically, before learning to write, children must go through some stages, such as listening, speaking and reading. In developing the competency of beginner-level writing for students of early grade in elementary school, a fun method must be used so that children can participate in activities well and without feeling depressed. One of the methods is known as edutainment. Edutainment is a combination of educational content that is presented with entertainment which aims at stimulating children to learn beginnerlevel writing through fun and interesting activities. Learning beginner-level writing with edutainment methods can be done with a variety of games, role playing activities or involvement of attractive learning media. With the edutainment method, children will not feel bored in learning beginner-level writing.
\end{abstract}

Keywords: edutainment, beginner-level writing

\begin{abstract}
Abstrak
Menulis permulaan merupakan salah satu dimensi perkembangan bahasa anak sekolah dasar (SD) kelas awal yang juga harus mendapat perhatian. Menulis merupakan tahap akhir pembelajaran literacy. Secara teoritis, sebelum belajar menulis anak-anak harus melalui tahap-tahap, seperti menyimak, mendengar, dan bicara serta membaca. Dalam mengembangkan kemampuan menulis permulaan anak SD kelas awal tersebut haruslah menggunakan metode yang menyenangkan agar anak dapat mengikuti kegiatan dengan baik dan tanpa ada rasa tertekan. Salah satu metode yang dimaksud dikenal dengan edutainment. Edutainment merupakan kombinasi dari fungsi pendidikan dalam konten yang disajikan dengan hiburan yang dapat ditujukan untuk menstimulasi anak dalam kegiatan menulis permulaan melalui kegiatan yang menarik dan menyenangkan bagi peserta didik. Pembelajaran menulis permulaan dengan metode edutainment dapat dilakukan dengan berbagai permainan (game), bermain peran ataupun melibatkan multimedia. Dengan metode edutainment, anak tidak akan merasakan kejenuhan atau kebosanan lagi dalam belajar menulis permulaan.
\end{abstract}

Kata kunci: edutainment, menulis permulaan 


\section{PENDAHULUAN}

Kegiatan belajar bagi seorang anak merupakan proses yang kompleks, karena belajar tidak hanya menyerap informasi dari guru saja, melainkan dapat terjadi interaksi antara individu dengan individu, dan individu dengan lingkungannya. Selain itu belajar melibatkan proses kognitif dan perubahan yang terjadi akibat adanya pengalaman dan latihan.

Pembelajaran yang terjadi pada peserta didik tidak semata-mata hanya berfokus pada satu perkembangan saja namun melibatkan aspek perkembangan yang lainnya juga, termasuk perkembangan bahasa. Perkembangan bahasa pada anak meliputi empat kemampuan yaitu kemampuan mendengar, berbicara, membaca, dan menulis. Menurut [1], tujuan pengembangan bahasa untuk anak adalah agar anak mampu mengkomunikasikan ide dan perasaan serta mampu mengintepretasikan komunikasi yang diterimanya. Dari pendapat tersebut dapat dinyatakan bahwa fungsi bahasa yang utama adalah sebagai alat komunikasi.

Anak-anak memperoleh kemampuan berbahasa dengan cara yang sangat menakjubkan. Menurut [2], "pada akhir masa dininya, ratarata anak telah menyimpan lebih dari 14.000 kosa kata”. Pada perkembangan selanjutnya, anak mampu menambah kosa kata secara mandiri dalam bentuk komunikasi yang baik. Kemampuan tersebut lebih ditegaskan pula oleh Papalia, et.al., yang membahas lebih spesifik tentang tentang kemampuan berbicara pada anak usia dini tersebut. Menurutnya, kamampuan bicara anak pada usia 5-7 tahun sudah mampu melakukan percakapan seperti orang dewasa.
Anak berbicara dengan kalimat yang lebih panjang dan lebih kompleks, banyak menggunakan kata sambung dan preposisi. Namun, anak belum menguasai titik kefasihan bahasa [3] .Anak yang belum terlalu fasih menguasai bahasa akan terlihat jarang dalam menggunakan kalimat pasif.

Salah satu dimensi perkembangan bahasa anak SD kelas awal yang juga harus mendapat perhatian adalah kemampuan menulis permulaan. Kemampuan menulis anak-anak mengikuti urutan perkembangan. Kemampuan ini muncul dari coretan-coretan sebelumnya dan pertama-pertama tersebar secara acak di seluruh halaman, karateristik ini mencerminkan pemahaman yang tidak lengkap tentang batas-batas kata dan juga ketidakmampuan menciptakan satu baris dalam pikiran untuk menempatkan huruf-huruf. Anak-anak menemukan ejaan dengan melakukan penilaian tentang bunyi dan dengan menghubungkan bunyi yang mereka dengar dengan huruf yang mereka kenal. Snow dikutip [4] menjelaskan dalam mencoba untuk menunjukkan apa yang didengar, anak biasanya menggunakan nama-nama huruf alihalih bunyi huruf; vokal pendek sering dihilangkan karena tidak langsung berhubungan dengan nama-nama huruf.

Pada dasarnya anak memiliki tahap yang berbeda-beda dalam menulis sesuai dengan kematangannya. Untuk kematangan kemampuan menulis, selain aspek kognitif, dari aspek motorik juga diperlukan yaitu motorik halus. Aspek ini berperan untuk membantu anak mengkoordinasikan mata dan tangannya dalam menulis. 


\section{Berdasarkan karakteristik} aspek perkembangan yang telah dijabarkan tersebut, masing-masing aspek tidak dapat berdiri sendiri. Kognitif anak sangat berperan dalam pengembangan bahasa, motorik, dan social [5]. Demikian pula aspek lain sangat berpengaruh satu sama lain.

Pada usia 6 tahun, perkembangan bahasa anak mengalami ledakan yang diikuti oleh masa transisi yang dramatis, yaitu perpindahan dari ekspresi diri yang hanya bersifat oral ke eskpresi diri yang tertulis. Pada periode ini, kosa kata reseptif anak bertambah, bukan saja lewat mendengar, tetapi juga lewat membaca, dan kosa kata ekspresif anak meluas dari komunikasi lisan ke komunikasi tertulis.

Pernyataan di atas memberikan gambaran bahwa kemampuan menulis permulaan anak haruslah distimulasi dengan benar sejak dini. Kemampuan menulis permulaan anak akan berpengaruh terhadap kemampuannya di masa yang akan datang. Dengan demikian, diperlukan suatu metode yang dapat digunakan untuk menstimulasi kemampuan menulis permulaan yang dapat dengan mudah diterima oleh anak. Salah satu metode yang dimaksud adalah edutainment.

Edutainment dapat mengkemas kegiatan pembelajaran menjadi kondusif, menyenangkan dan menimbulkan perasaan bebas (tidak ada tekanan) pada diri anak.

Mengingat anak SD kelas awal merupakan bagian dari anak usia dini, maka kegiatan pembelajarannya pun seharusnya masih dikemas dalam suasana bermain dan menyenangkan. Metode pembelajaran yang menyenangkan dapat menciptakan iklim belajar yang kondusif dan bermakna. Anak tidak akan merasakan jenuh atau bosan dalam menerima pembelajaran.

Berdasarkan uraian di atas, maka dirasa sangat tepat apabila metode edutainment juga diterapkan pada kegiatan menulis permulaan di SD kelas awal. Pembelajaran yang sesuai dengan karakteristik anak dapat membantu anak mencapai tujuan pembelajaran yang diharapkan dengan maksimal.

Penelitian ini merupakan jenis penelitian pustaka (library research), yaitu penelitian yang dilakukan dengan memahami referensi melalui buku literatur atau media internet. Data dan informasi yang digunakan dalam penelitian ini berupa buku-buku yang selanjutnya secara kualitatif diuraikan dan dianalisis.

\section{PEMBAHASAN}

\subsection{Kemampuan Bahasa Anak}

Bahasa merupakan bentuk komunikasi baik lisan maupun tulisan atau tanda yang didasarkan pada sistem simbol. [6] menyatakan bahwa bahasa merupakan rangkaian bunyi yang melambangkan pikiran, perasaan dan sikap manusia. Hal tersebut berarti bahwa bahasa merupakan sistem lambang. Dengan demikian, orang dapat berpikir dan berbicara secara abstrak dan kongkrit sesuai dengan lambang yang dipikirkan.

Bahasa merupakan sasaran utama untuk berpikir dan bernalar. Manusia berpikir dengan menggunakan otak dan mengolah pikirannya tersebut melalui bahasa. Dengan bahasa, manusia dapat menyampaikan hasil pemikiran atau penalaran, sikap, serta perasaannya. Ia dapat bergaul dan berkomunikasi, mencari informasi, serta mengendalikan pikiran, sikap, 
dan perbuatan sesamanya dengan menggunakan bahasa.

Teori Nativist oleh Chomsky mengutarakan bahwa bahasa sudah ada di dalam diri anak. Pada saat seorang anak lahir, dia telah memiliki seperangkan kemampuan berbahasa yang disebut "Tata Bahasa Umum" atau 'Universal Grammar'. Meskipun pengetahuan yang ada di dalam diri anak tidak mendapatkan banyak rangsangan, anak akan tetap dapat mempelajarinya. Anak tidak sekedar meniru bahasa yang dia dengarkan, tapi ia juga mampu menarik kesimpulan dari pola yang ada, hal ini karena anak memiliki sistem bahasa yang disebut Perangkat Penguasaan Bahasa (Language Acquisition Devise/LAD). Teori ini berpengaruh pada pembelajaran bahasa dimana anak perlu mendapatkan model pembelajaran bahasa sejak dini. Anak akan belajar bahasa dengan cepat sebelum usia 10 tahun apalagi menyangkut bahasa kedua (second language). Lebih dari usia 10 tahun, anak akan kesulitan dalam mempelajari bahasa.

Bahasa memberi sumbangan yang besar bagi perkembangan diri anak. Dengan bantuan bahasa, anak mampu tumbuh menjadi pribadi yang yang dapat berpikir, merasa, bersikap, berbuat, serta memandang dunia dan kehidupan seperti orang-orang disekitarnya.

Anak menerima dan mengekpresikan bahasa dengan berbagai cara. Keterampilan menyimak dan membaca merupakan kerterampilan bahasa reseptif karena dalam keterampilan ini makna bahasa diperoleh dan diproses melalui simbol visual dan verbal. Ketika anak menyimak dan membaca, mereka memahami bahasa berdasarkan konsep pengetahuan dan pengalaman mereka. Dengan demikian menyimak dan membaca juga merupakan proses pemahaman. Berbicara dan menulis merupakan keterampilan bahasa ekpresif yang melibatkan pemindahan arti melalui simbol visual dan verbal yg diproses dan diekspresikan anak. Ketika anak berbicara dan menulis, mereka menyusun bahasa dan mengkosep arti. Dengan demikian berbicara dan menulis adalah proses penyusunan (composing process).

\subsection{Kemampuan Permulaan}

Menulis

Pengetahuan tentang tulisan mengacu pada semua konsep yang berkaitan dengan bagaimana suatu tulisan diorganisasi dan digunakan untuk menyampaikan suatu makna. Untuk memaknai bahasa tulisan, anak perlu memahami suatu bunyi, kata, dan kalimat yang tercetak. Mereka perlu mengetahui bahwa pikiran dan perasaan ditulis dengan cara tertentu.

Anak memahami tentang tulisan secara bertahap. Pemahaman ini didasarkan pada minat dan pengalaman anak terhadap bahasa. Anak perlu memahami bahwa tulisan menyampaikan suatu pesan, tetapi pesan yang dibawakan oleh tulisan berbeda dari pesan yang lisan. Mereka nantinya akan mengerti bahwa tulisan memiliki berbagai tujuan, memiliki bentuk yang berbeda, dikelola secara berlainan, dan dapat ditemukan dalam beragam teks.

Langkah awal dalam mengajarkan menulis pada anak adalah membantu anak-anak untuk menguasai alat dan mengendalikan kegiatan coret-mencoret yang sangat 
anak gemari [7]. Semua pekerjaan persiapan dilakukan dengan pensil lunak berukuran besar atau krayon/alat-alat yang dapat dipegang anak tanpa kesulitan. Semua gerakan yang dituntut bersifat luas, bebas, berirama, dan tidak dikekang oleh aturan-aturan petunjuk yang membatasi.

Ada lima kemampuan yang diperlukan untuk dapat menulis, yaitu: (1) mengenal bentuk, (2) mengenal perbedaan bunyi huruf, (3) mengenal rangkaian pola, (4) kekuatan jari-jari tangan, dan (5) kelenturan gerakan pergelangan tangan. Kemampuan menulis dibentuk melalui suatu proses. Ada delapan tahapan yang dilalui anak dalam pembentukan kemampuan menulis, yaitu coretan acak atau tidak terkendali, coretan terarah dan terkendali, pengulangan garis menjadi suatu bentuk, membuat suatu bentuk yang lebih jelas, menulis nama, meniru tulisan, menemukan ejaan atau kata, dan ejaan standar.
Delapan tahap kemampuan menulis yang diuraikan oleh Kemdiknas tersebut merupakan penjabaran dari tahap-tahap perkembangan menulis anak-anak Barat. Stimulasi bahasa tulis aktifproduktif atau pembelajaran menulis sebagaimana juga pembelajaran membaca, perlu memperhatikan bahasa tulis anak. Sulzby mendeskripsikan sebuah urutan bentuk-bentuk menulis yang muncul pada anak-anak begitu mereka mulai menulis [8]. Tahap-tahap perkembangan menulis anak-anak Barat yang dimaksud, yaitu: (1) tahap mencoret (scrible stage), (2) tahap pengulangan linier (linier repetitive stage), (3) tahap huruf acak (random letter stage), (4) tahap menulis fonetik (phonetic writing stage), (5) tahap eja transisi (transitional spelling stage), dan (6) tahap eja konvensional (conventional spelling stage). 
Tabel 2.1 Tahapan Kemampuan Menulis

\begin{tabular}{|c|c|c|}
\hline Tahapan & Usia & Bentuk Tulisan \\
\hline $\begin{array}{l}\text { Tahap Mencoret } \\
\text { Coretan-coretan yang dibuat } \\
\text { seolah-olah tidak putus dan } \\
\text { berhenti. Coretan mulai } \\
\text { menunjukkan suatu bentuk } \\
\text { atau rancangan. Menurut } \\
\text { anak, ia menggambar ikan. }\end{array}$ & 2- 3,5 Tahun & \\
\hline $\begin{array}{l}\text { Tahap Pengulangan Linier } \\
\text { Dari hasil pengulangan akan } \\
\text { semakin jelas bentuk yang } \\
\text { dihasilkan. Misalnya, ikan } \\
\text { atau huruf. }\end{array}$ & 3,5 - 4 Tahun & \\
\hline $\begin{array}{l}\text { Tahap Huruf Acak } \\
\text { Semakin terbentuk tulisan } \\
\text { yang dibuat anak. Anak } \\
\text { mulai } \\
\text { identitasnya, menunjukkan } \\
\text { dan gambar. }\end{array}$ & $4,5-5$ Tahun & \\
\hline $\begin{array}{l}\text { Tahap Menulis Fonetik } \\
\text { Anak mulai suka meniru } \\
\text { tulisan yang dilihatnya, } \\
\text { misalnya dari Koran atau } \\
\text { majalah }\end{array}$ & $5-6$ Tahun & 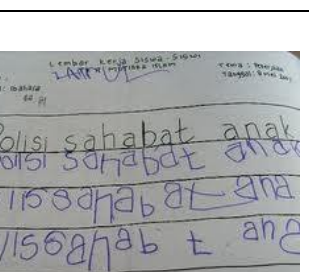 \\
\hline $\begin{array}{l}\text { Tahap Eja Transisi } \\
\text { Menulis respon pada } \\
\text { sesuatu. } \\
\text { ditunjukkan sejumlah benda, } \\
\text { anak menuliskan nama- } \\
\text { nama benda itu }\end{array}$ & 5,5 - 6 Tahun & \\
\hline $\begin{array}{l}\text { Tahap Eja Konvensional } \\
\text { Anak dapat mengeja kata } \\
\text { dengan benar dan mampu } \\
\text { menggabungkan kata-kata } \\
\text { menjadi kalimat }\end{array}$ & 6 Tahun $<$ & $\begin{array}{l}\text { AkU Berangkat } \\
\text { Ke Sekolah }\end{array}$ \\
\hline
\end{tabular}

Sumber: [9] 


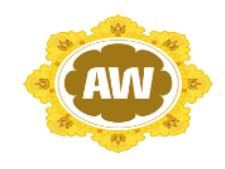

Volume. 4, Nomor 2 Oktober 2019

ISSN: 2685-8312 (online)

ISSN: 2527-5445 (cetak

http://ejournal.ihdn.ac.id/index.php/AW
Menurut [10], "menulis juga merupakan tahap akhir pembelajaran literacy". Secara teoritis, sebelum belajar menulis anak-anak harus melalui tahap-tahap, seperti menyimak, mendengar, dan bicara serta membaca. Setelah semua tahapan ini dikuasai, barulah pembelajaran menulis dimulai.

Penulisan yang dimaksud di sini bukan sekedar penguasaan motorik halus, tetapi kemampuan mengekspresikan diri dengan gambar dan coretan yang bermakna. Kemampuan menulis berkembang bila anak sudah terampil memegang alat tulis maupun memiliki kelenturan menggerakkan pergelangan tangannya. Sebelum mampu menulis biasanya anak sudah diberi kegiatan bebas terbuka seperti bermain dengan lilin, menggambar, melukis, membentuk dengan balok, lego, dan sejenisnya. Semua merupakan kegiatan yang bisa dipersiapkan, sehingga anak menguasai bahasa secara alamiah.

Belajar menulis anak tidak boleh hanya terpusat pada pembenahan tulisan anak, melainkan pada susunan huruf menjadi kata, dan menyusun kata menjadi kalimat. Montessori [11] menyatakan bahwa "begitu anak mengetahui suara dan bentuk vokal dan konsonan yang cukup, mereka siap untuk menulis." Satu-satunya penghalang bagi anak adalah ketidakmampuan untuk mengendalikan pensil. Dengan kata lain, masa awal anak belajar menulis adalah membuat kata atau kalimat dengan tulisan "cakar ayam".
Modal terbesar anak-anak dapat mmenulis kalimat secara sempurna adalah kegemaran membaca. Sebab, apa yang akan ditulis anakanak adalah apa yang sedang dipikirkannya. Adapun hal yang ada di dalam pikiran anak tersebut adalah informasi yang diperolehnya dari membaca. Dengan demikian, untuk dapat menulis dengan lancar, maka kegemaran membaca pada anak harus ditingkatkan.

Montessori [12] menyatakan bahwa membaca dan menulis saling berjalinan satu sama lain, biasanya menulis mendahului aktivitas membaca aktual. Keseimbangan antara membaca dan menulis akan sangat membantu anak-anak menuangkan ide dan gagasannya dalam bentuk tulisan, seperti surat, puisi, pantun, dan lainlain. Sehingga, anak-anak tidak hanya pandai bercerita saja, tetapi juga pandai menulis.

Pernyataan Montessori tersebut juga diperkuat oleh [13] yang menyatakan bahwa membaca dan menulis sangat berkaitan yaitu dihasilkan dengan proses pengalaman yang sama, sama-sama menggunakan simbol verbal. Anak yang belajar menulis pada kesempatan yang sama anak belajar membaca pula. Dengan demikian, kemampuan membaca dan menulis tidak dapat dipisahkan satu sama lain. Anak belajar menulis, secara tidak langsung ia belajar membaca. Demikian pula sebaliknya ketika anak mengenali huruf-huruf yang terdapat pada kalimat, anak mencoba untuk meniru huruf-huruf tersebut melalui tulisan. Menurut 


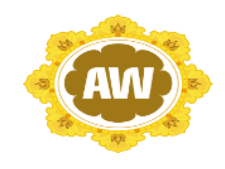

Volume. 4, Nomor 2 Oktober 2019

ISSN: 2685-8312 (online)

ISSN: 2527-5445 (cetak

http://ejournal.ihdn.ac.id/index.php/AW
Plooter yang dikutip oleh Eliason dan Jenkins [14] menyatakan "seorang pembaca yang baik akan menjadi penulis yang baik juga". Menulis memerlukan kemampuan motorik halus, koordinasi mata dan tangan cara memegang peralatan menulis, cara penulisan persepsi huruf, dan bahasa cetak.

Hohmann juga memberikan pandangan mengenai membaca dan menulis yang harus dilakukan bersamaan. Roskos, et. al. [12] mengatakan bahwa: "Young children need writing to help them learn about reading they need reading to need help them learn about writing; and they need oral language to help them learn about both." Anak-anak membutuhkan tulisan untuk membantu mereka belajar membaca, mereka membutuhkan bacaan untuk membantu mereka belajar menulis, dan mereka membutuhkan komunikasi lisan untuk membantu mereka belajar membaca dan menulis.

\subsection{Metode Edutainment dalam Pembelajaran Menulis Permulaan}

Dari asal katanya, edutainment terdiri dari dua kata yaitu education (pendidikan) dan entertainment (hiburan). Berdasarkan dua kata tersebut, edutainment berarti pendidikan yang menghibur atau menyenangkan [15]. Konsep edutainment ini adalah menggabungkan muatan pendidikan dengan hiburan sehingga pembelajaran menjadi menyenangkan.

Edutainment didesain untuk memfasilitasi peserta didik belajar dengan memasukkan unsur hiburan sehingga anak yang belajar tanpa ada perasaan tertekan atau terpaksa. Dengan demikian, dapat dikatakan bahwa edutainment merupakan suatu kegaitan pembelajaran yang dalam pelaksanaannya lebih mengedepankan kesenangan dan kegembiraan dalam mencapai tujuan pembelajaran.

\begin{tabular}{cr}
\multicolumn{2}{c}{ Pembelajaran menulis } \\
permulaan dengan metode
\end{tabular} edutainment dapat dilakukan dengan berbagai permainan (game), bermain peran ataupun melibatkan multimedia. Berbagai permainan, nyanyian ataupun hiburan yang melibatkan perangkat multimedia dapat menjadi salah satu solusi dari fenomena yang terjadi selama ini yaitu bahwa kegiatan menulis merupakan sesuatu yang menimbukan kebosanan atau kejenuhan pada peserta didik.

Menurut Hamruni [16] terdapat tiga alasan yang melandasi munculnya konsep edutainment, yaitu:

a) Perasaan positif (senang/gembira) yang dapat mempercepat penerimaan isi pembelajaran. Sedangkan perasaan negatif dapat memperlambat proses penyerapan informasi.

b) Apabila peserta didik mampu menggunakan potensi nalar dan emosinya dengan baik, maka akan menimbulkan loncatan prestasi belajar yang tidak terduga sebelumnya.

c) Apabila setiap peserta didik dapat dimotivasi dengan tepat dan diberikan kegiatan pembelajaran dengan cara yang benar, cara yang menghargai gaya dan modalitas 
ADI WIDYA: Jurnal Pendidikan Dasar

FAKULTAS DHARMA ACARYA

INSTITUT HINDU DHARMA NEGERI
Volume. 4, Nomor 2 Oktober 2019

ISSN: 2685-8312 (online)

ISSN: 2527-5445 (cetak

http://ejournal.ihdn.ac.id/index.php/AW belajar mereka, maka semua peserta didik akan mencapai hasil belajar yang optimal.

Maka dari itu pada hakekatnya konsep edutainment berupaya untuk menciptakan suatu pembelajaran yang nyaman dan menyenangkan bagi peserta didik. Kesenangan dan kegembiraan dalam hal ini berarti bangkitnya minat, adanya keterlibatan penuh, terciptanya makna (kepuasan pribadi), pemahaman materi dan nilai yang membahagiakan peserta didik.

Menurut Nemec and Josef [17], "edutainment is a distinctive form of entertainment that enables the participants to be educated (e.g. get new information fro various fields of our life) or even brought up (their postures, values and behavioural patterns could be influenced)". Pernyataan tersebut mendukung bahwa edutainment merupakan suatu bentuk khas dari hiburan yang memungkinkan anak mendapat pembelajaran, seperti mendapatkan informasi baru dari berbagai pengalaman dari kehidupan anak dan anak dapat mengetahui nilainilai serta pola perilaku yang dapat mempengaruhi perilakunya.

Berdasarkan uraian di atas, dapat disimpulkan bahwa edutainment merupakan kombinasi dari fungsi pendidikan dalam konten yang disajikan dengan hiburan yang dapat ditujukan untuk menstimulasi anak dalam kegiatan menulis permulaan melalui kegiatan yang menarik dan menyenangkan bagi peserta didik. Dengan metode edutainment, anak tidak akan merasa jenuh atau bosan dalam belajar menulis permulaan.

\section{PENUTUP}

Pembelajaran

menulis

permulaan merupakan salah satu aspek perkembangan bahasa yang penting untuk distimulasi. Menulis permulaan juga masuk ke dalam mata pelajaran bahasa pada anak SD kelas awal. Pembelajaran ini tidak dapat dipandang sebelah mata dikarenakan masuk ke dalam pembelajaran literacy yang berpengaruh besar terhadap kemampuan anak. Terdapat enak tahap perkembangan menulis permulaan, yaitu: Tahap-tahap perkembangan menulis anak-anak Barat yang dimaksud, yaitu: (1) tahap mencoret (scrible stage), (2) tahap pengulangan linier (linier repetitive stage), (3) tahap huruf acak (random letter stage), (4) tahap menulis fonetik (phonetic writing stage), (5) tahap eja transisi (transitional spelling stage), dan (6) tahap eja konvensional (conventional spelling stage).

Tahapan menulis permulaan tersebut merupakan landasan atau pengetahuan dalam memahami bagaimana anak memiliki kemampuan menulisnya. Secara karakteristik, anak SD kelas awal masih dalam kategori anak usia dini, sehingga pembelajarannya pun harus diberikan dengan cara yang menyenangkan agar anak tidak merasa tertekan.

Berdasarkan hal tersebut, dalam pembelajaran menulis permulaan anak SD kelas awal dapat menggunakan metode edutainment. Edutainment merupakan kombinasi dari fungsi pendidikan dalam konten 
ADI WIDYA: Jurnal Pendidikan Dasar

FAKULTAS DHARMA ACARYA

INSTITUT HINDU DHARMA NEGERI

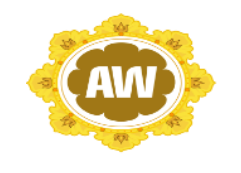

Volume. 4, Nomor 2 Oktober 2019

ISSN: 2685-8312 (online)

ISSN: 2527-5445 (cetak

http://ejournal.ihdn.ac.id/index.php/AW yang disajikan dengan hiburan yang dapat ditujukan untuk menstimulasi anak melalui kegiatan yang menarik dan menyenangkan. Dengan metode ini, anak tidak akan merasa jenuh dan bosen sehingga pembelajaran lebih bermakna.

\section{DAFTAR PUSTAKA}

[1] A. P. W. Kostelnik, Marjorie J., Anne K. Soderman, Developmentally Appropriate Curriculum. USA: Pearson, 2007.

[2] Suyadi, No TitlePsikologi Belajar PAUD. Yogyakarta: Pedagogia, 2010.

[3] D. E. et. a. Papalia, Human Development. Jakarta: Kencana, 2008.

[4] R. E. Slavin, Psikologi Pendidikan: Teori dan Praktik. Jakarta: Indeks, 2008.

[5] K. A. Prima Dewi PF, "GERAKAN SURYA

NAMASKAR SEBAGAI METODE PENAPISAN DASAR ANAK USIA DINI," PRATAMA WIDYA J. Pendidik. ANAK USIA DINI, 2019.

[6] Suhartono, Pengembangan Kemampuan Berbicara Anak Usia Dini. Jakarta: Departemen Pendidikan Nasional Direktorat Jendral Pendidikan Tinggi

Direktorat Pembinaan Pendidikan Tenaga Kependidikan dan Ketenagaan
Perguruan Tinggi., 2005.

[7] A. G. \& E. H. H. Hughes, Learning \& Teaching. Bandung: Nuansa, 2012.

[8] T. Musfiroh, Menumbuhkembangkan BacaTulis Anak Usia Dini. Jakarta: Grasindo, 2009.

[9] J. A. Brewer, Early Childhood Education. USA: Pearson, 2007.

[10] Suyadi, Psikologi Belajar PAUD. Yogyakarta: Pedagogia, 2010.

[11] S. Feez, Montessori and Early Childhood. Singapore: SAGE, 2010.

[12] D. Mutiah, Psikologi Bermain Anak Usia Dini. Jakarta: Kencana, 2010.

[13] L. M. Marrow, Literacy Development In Early Years, Second Edi. USA: Allyn \& Balcon, 1993.

[14] A. Susanto, Perkembangan Anak usia Dini: Pengantar Dalam Berbagai Aspeknya. Jakarta: Kencana, 2011.

[15] E. Widiasworo, Strategi Pembelajaran Edutainment Berbasis Karakter. Yogyakarta: AR-Ruzz Media, 2018.

[16] Fadlillah, Edutainment Pendidikan Anak Usia Dini. Jakarta: Kencana, 2014.

[17] J. \& J. T. Nemec, Edutainment or Entertainment (Education Possibilitiesof Didactic Games in Science Education. Czech Republic, 2002. 